\title{
Spatial Distribution and Influence Analysis of Soil Heavy Metals in a Hilly Region of Sichuan Basin
}

\author{
Hanhu Liu*, Guanghui Liu, Yunfan Zhou, Chao He \\ The Ministry of Land and Resources Key Laboratory of Geological Spatial Information Technology, \\ College of Earth Sciences, Chengdu University of Technology, \\ Chengdu, 610059, China
}

Received: 27 May 2016

Accepted: 8 September 2016

\begin{abstract}
The hilly region of the Sichuan basin has unique natural topography, geomorphology, geology, and hydrology, with intensive human activities in the area. Therefore, it is of great significance to carry out research on heavy metal characteristics. In this study, taking five villages of Zigong city as a sample, the content of eight kinds of heavy metals in soil was determined $(\mathrm{Cu}, \mathrm{Cd}, \mathrm{As}, \mathrm{Pb}, \mathrm{Cr}, \mathrm{Zc}, \mathrm{Ni}$, and $\mathrm{Hg}$ ) based on ordinary Kriging. The results showed that $\mathrm{Cd}, \mathrm{Pb}, \mathrm{Ni}$, and $\mathrm{Zn}$ content in the research area was higher than the background value and had a good concentration with all of the heavy metal contents lying within the national standards. Through soil parent material, soil environment, atmospheric environment, and water environment analysis of heavy metals, it was found that higher levels of heavy metals in the research area were mainly affected by agricultural and industrial activities (atmospheric dustfall). This was generally where there were intense areas of human activity - especially in and around transport routes and construction areas. It was also found that the soybean crop exhibited a strong $\mathrm{Cd}$ accumulation ability. This soybean planting should be reduced to control the distribution of $\mathrm{Cd} . \mathrm{Zn}$ and $\mathrm{Cu}$ had a positive enrichment effect on rice, soybeans, and other crops, and had little enrichment effect on grapefruit. This study showed the effect human activities have on the quality of soil quality on the crop. This research has great significance for the ecologically sustainable development of society.
\end{abstract}

Keywords: heavy metals, soil environment, atmospheric dustfall, Sichuan, hilly region of Sichuan basin

\section{Introduction}

Soil is a key component of the terrestrial ecosystem and plays an essential role in food production, biochemical transformations, recycling of elements, and many

*e-mail: pjoes_mces@hotmail.com recreational activities [1]. With rapid industrialization and urbanization, as well as extensive application of agrochemicals, heavy metal pollution of soil has increasingly become a serious problem in China [23]. Agricultural land includes farmland, forestland, and grassland, and contamination of these types of soils with heavy metals is attracting considerable attention because of the potential threat to farmland, forestland, and grassland ecosystems [4-5]. Anthropogenic contamination 
- including excessive use of fertilizers and pesticides, irrigation with sewage water, and elevated atmospheric deposition - is the main source of the existence of heavy metals in agricultural soils [6-8]. Heavy metal contamination in soil exhibits specific pollutant characteristics as they do not decay over time and can be toxic to plants when they exceed specific thresholds. At the same time, accumulation of heavy metals in soil has the potential to inhibit the proper functioning of soil, causing toxicity to plants and promote heavy metals to humans [9-10].

Agricultural production plays a key role in the development of China. However, with rapid industrialization, urbanization and increasing reliance on agrochemicals, heavy metal contamination in soil has become severe during the last two decades [11-12]. In the past decade, numerous studies have reported the concentration, distribution, and sources of heavy metals in Chinese soil [13-14]. However, most of these studies have focused on urban soil $[13,15]$ and only a few on rural, agricultural land - especially in the hilly region of the Sichuan basin.

Much food and other materials for daily life are produced in the hilly region of the Sichuan basin. Rapid economic development and increases in population have put an enormous pressure on the ecosystems and soil ecological environments in these regions. Combined with the development of various industrial activities, at the expense of the environment and the impact of rural-point source pollution, the land-bearing load is saturated in the hilly region of the Sichuan basin. This has brought about a series of consequences; for example, serious degradation of soil ecological environment, soil environmental quality is decreasing year by year and soil pollution problems have become increasingly prominent. In light of the above, this study has carried out heavy metal pollution and the distribution characteristics in soil of five villages in Zigong city and the control factors have been discussed.

\section{Materials and Methods}

\section{Study Area}

The study area is located in the central Sichuan basin in China. The size of the research area from east to west is $4.3 \mathrm{~km}$ long and $5.0 \mathrm{~km}$ wide from north to south.

The climate in this region is subtropical, humid, and susceptible to monsoons, and has four distinct seasons. The annual average temperature is $17.8^{\circ} \mathrm{C}$ and the accumulated temperature is $6021.0^{\circ} \mathrm{C}$. The year round sunshine is $1200-1280$ hours, the average annual precipitation is $1031-1041 \mathrm{~mm}$, and average annual rainfall is 140 days. The characteristic of the terrain is high in the northwest, low in the southeast, with a creek widely distributed among small hills and a narrow mesa. There are some areas that have exposed bedrock in the research area, but most of the rest is in the quaternary. In the bedrock outcropping is Jurassic Shaximiao $\left(\mathrm{J}_{2} \mathrm{~s}\right)$, and the lithology is purple, brownish red mudstone, and unstable feldspar quartz siltstone interbedded. Quaternary alluvial material is divided into (Qpal) and alluvial material (Qdpl), scattered in the vicinity of the river terraces and Pingba, and the lithology is mainly packed clay and gravel with a gravel floodplain.

\section{Collection of Samples}

Soil samples were collected following the method in reference [16]. Sampling points were set in a 1:10,000 topographic map. The sampling density was $16 \mathrm{~kg} / \mathrm{km}^{2}$ and the sampling unit was $250 \mathrm{~m} \times 250 \mathrm{~m}$. The research area was divided into 173 sampling cells (Fig. 1) and soil samples were collected for testing. As and $\mathrm{Hg}$ content in soil samples were estimated by the atomic fluorescence method. The content of $\mathrm{Cr}, \mathrm{Cu}, \mathrm{Ni}, \mathrm{Pb}$, and $\mathrm{Zn}$ was determined by $\mathrm{x}$-ray fluorescence, and plasma mass
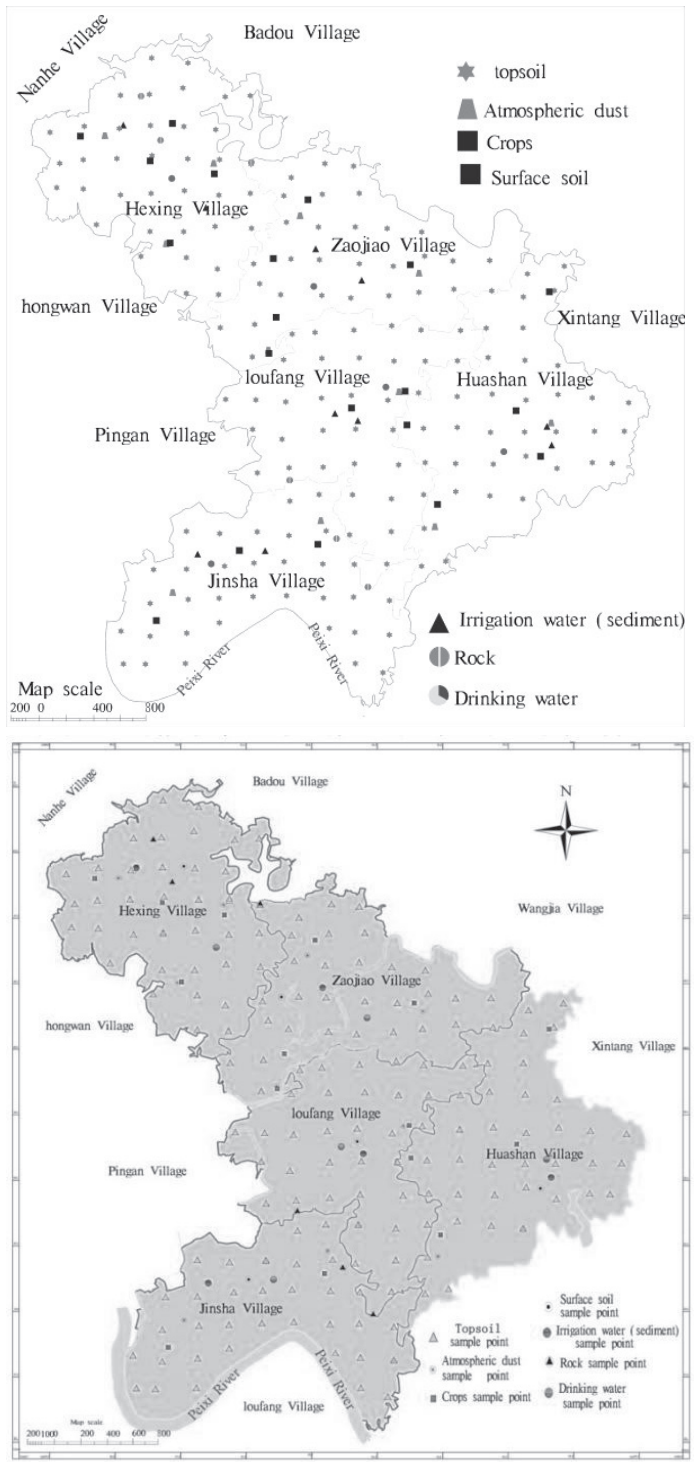

Fig. 1. Distribution of samples and sampling position in the study area. 
spectrometry was used to determine the Cd content in soil samples [17].

Soil samples were collected by digging soil about 30 $\mathrm{cm}$ between locations, placed at different levels according to the level of soil excavated. Records were kept of profile number (field number), soil name (field naming), soil color, soil structure, mining land points, terrain (plus notes on parent material, vegetation, altitude, etc., if necessary), hunters, and acquisition date.

Atmospheric dustfall samples were collected from the windows of residential buildings and public facilities. While sampling, direct sources of pollution such as industrial pollution, civil coal, and peeling paint, etc., should be avoided. Each sample was made by mixing equal amounts of 3-4, collecting approximately $20 \mathrm{~g}$.

Irrigation water samples were collected from the main irrigation water intake. The water intake section was generally laid on a larger main stream, and the control was less than $80 \%$ of the total runoff flow. Drinking water samples were collected at the typical model of the centralized water supply and untreated water sources with a sampling density of $1 \mathrm{~kg} / \mathrm{km}^{2}$. Well-water samples were collected from residential wells. While collecting irrigation water, sediment samples were also collected.

According to the actual situation in the research area, grain crops were chosen from rice, wheat, corn, sweet potato, and vegetables, with eggplant and pepper being the most commonly harvested. While collecting plant samples, plant roots and soil were collected at the same time. The plants were generally uprooted, shaking the soil under the plant roots and removing plant roots and other debris.

\section{Quality Assurance and Quality Control}

Soil standard reference material (GBW07401, GSS-1) obtained from the Center of National Standard Reference Material of China was used for quality assurance and quality control (QA/QC). Accepted recoveries ranged from $81.0-109 \%$. Analysis methods were evaluated in blank $(n=7)$ and duplicate samples $(n=13)$ for each set of samples. Relative deviation of duplicate samples was $<7 \%$ for all the batch treatments.

\section{Data Analysis Methods}

Ordinary Kriging is a moving weighted average method that uses variograms constructed to interpolate between samples by considering the shape, size, and relative positions of samples within the database [1820]. These variograms are calculated by the following equation:

$$
\gamma(h)=\frac{1}{2 N(h)} \sum_{i=1}^{N(h)}\left[Z\left(x_{i}\right)-Z\left(x_{i}+h\right)\right]^{2}
$$

...where $\gamma(\mathrm{h})$ is the variogram, $\mathrm{Z}$ (xi) is the sample value at location $\mathrm{I}, \mathrm{h}$ is lag distance, and $\mathrm{N}(\mathrm{h})$ is the number of data pairs within lag distance [21].

\section{Results and Discussion}

This paper collected 173 samples of surface soil and, using various testing methods, obtained the content of eight heavy metals in the topsoil, and conducted a statistical analysis. Table 1 shows the maximum and minimum values of elements in the test sample. $\mathrm{X} 1$ is the average of all elements in the sample, $\mathrm{S} 1$ is the standard deviation of the measured values of deviation of the sample mean, and $\mathrm{Cv}$ is the coefficient of variation (the standard from the difference between the ratio of the arithmetic mean, $\mathrm{Cv}=\mathrm{S} / \mathrm{X} 1)$. The average concentrations of As, $\mathrm{Cd}, \mathrm{Cr}, \mathrm{Cu}, \mathrm{Pb}, \mathrm{Ni}, \mathrm{Zn}$, and $\mathrm{Hg}$ were $3.58,0.49,75.49$, $27.95,29.93,33.30,95.85$, and $0.05 \mu \mathrm{g} / \mathrm{g}$, respectively. Background concentrations of these heavy metals in the soils of Sichuan Province are 9.3, 0.07, 79, 29.7, 28.9, 32.6, 82.1, and $0.04 \mu \mathrm{g} / \mathrm{g}$ for $\mathrm{As}, \mathrm{Cd}, \mathrm{Cr}, \mathrm{Cu}, \mathrm{Pb}, \mathrm{Ni}, \mathrm{Zn}$, and $\mathrm{Hg}$, respectively [22]. The Chinese Environmental Quality Standard for Soils [23] provides critical values for heavy metal concentration in soil for the protection of agricultural products and human health, and these are $25,1.0,250,200,350,300$, and $1.0 \mu \mathrm{g} / \mathrm{g}$ for As, Cd, Cr, $\mathrm{Cu}, \mathrm{Pb}, \mathrm{Zn}$, and $\mathrm{Hg}$, respectively. In this study, $\mathrm{Cd}$ content was exceeded only in five samples. Although the heavy metal concentrations in the majority of the samples did not exceed the national guideline values, the obvious enrichment of these metals in the research area should be noted.

In the analysis of heavy metals in terms of distribution, the coefficient of variation can eliminate the influence of objective measurement scales and make it more dimensionless than the standard deviation. In Table $1, \mathrm{Cd}$ and $\mathrm{Hg}$ coefficients of variation were significantly higher than those of the other elements, showing that aggregation was worse in these two elements.

Understanding the spatial distribution soil heavy metals in soil is a significant prerequisite for monitoring and evaluating the eco-environment in the research area. The spatial distribution of heavy metals in soil of the hilly region of the Sichuan basin was visualized by drawing distribution maps of eight heavy metals using ArcGIS.

Table 1. Total amount of statistical indicators of soil surface characteristics $(\mathrm{n}=173 ; \mu \mathrm{g} / \mathrm{g})$.

\begin{tabular}{|c|c|c|c|c|c|}
\hline Element & Max & Min & $\mathrm{X}_{1}$ & $\mathrm{~S}_{1}$ & $\mathrm{Cv}$ \\
\hline $\mathrm{As}$ & 5.83 & 2.03 & 3.58 & 0.66 & 0.18 \\
\hline $\mathrm{Cd}$ & 4.03 & 0.16 & 0.49 & 0.39 & 0.86 \\
\hline $\mathrm{Cr}$ & 124.00 & 59.90 & 75.49 & 7.13 & 0.09 \\
\hline $\mathrm{Cu}$ & 36.10 & 18.20 & 27.95 & 2.97 & 0.11 \\
\hline $\mathrm{Hg}$ & 0.19 & 0.02 & 0.05 & 0.02 & 0.42 \\
\hline $\mathrm{Ni}$ & 57.80 & 18.40 & 33.30 & 4.34 & 0.13 \\
\hline $\mathrm{Pb}$ & 38.20 & 22.70 & 29.93 & 2.73 & 0.09 \\
\hline $\mathrm{Zn}$ & 140.00 & 47.20 & 95.85 & 12.73 & 0.13 \\
\hline
\end{tabular}


According to the data, analysis of spatial interpolation was conducted based on 173 samples of the various elements, and this generated the corresponding grading evaluation map of $\mathrm{Hg}, \mathrm{Cd}, \mathrm{As}, \mathrm{Pb}, \mathrm{Cr}, \mathrm{Ni}, \mathrm{Cu}$, and $\mathrm{Zn}$ elements (Fig. 2). The maps show some distinct geographical trends, especially for $\mathrm{Cd}, \mathrm{Pb}, \mathrm{Ni}$, and $\mathrm{Zn}$, which were found to be higher than the background values in areas of high concentrations. A previous study [24] found that enrichment of $\mathrm{Cd}, \mathrm{Pb}$, and $\mathrm{Zn}$ in agricultural soil was closely correlated to agricultural production.

Fig. 2 shows that the content of heavy metals in topsoil was unevenly distributed in the research area.
The present study has determined three main sources of heavy metal pollution. The first source was lithogenic components, and was associated with soil parent materials [25-26]. The second source was from industrial activity such as vehicular transport [24, 27-28]. The third source was controlled by the anthropogenic inputs from agricultural production, such as chemical fertilizers [2930].

The original rock is the material basis for soil formation. In the corresponding biological climate condition, the surface of the original rock is gradually turned into soil through physical and chemical weathering,
As

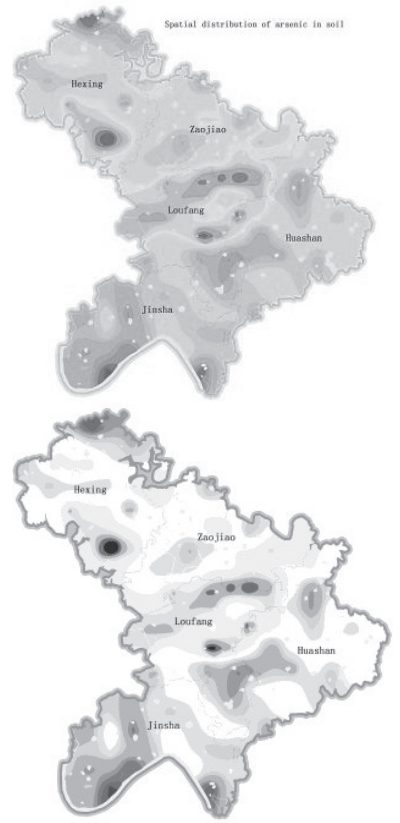

$\mathrm{Hg}$

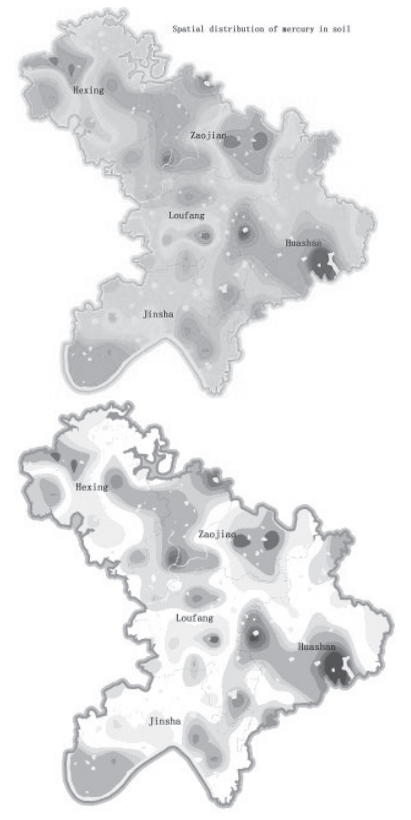

$\mathrm{Cd}$
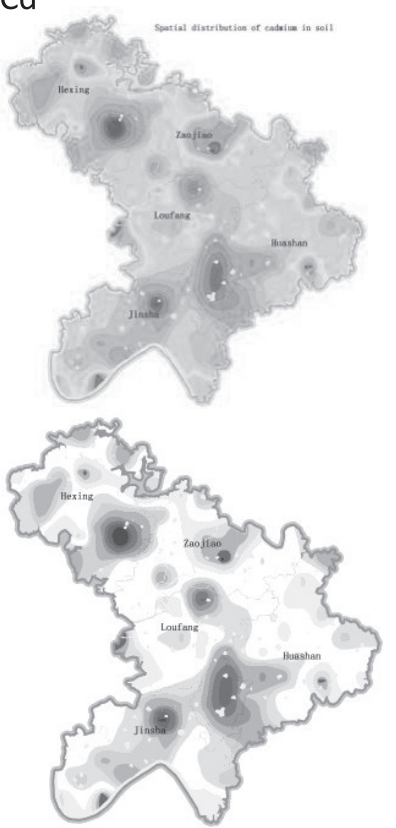

$\mathrm{Ni}$

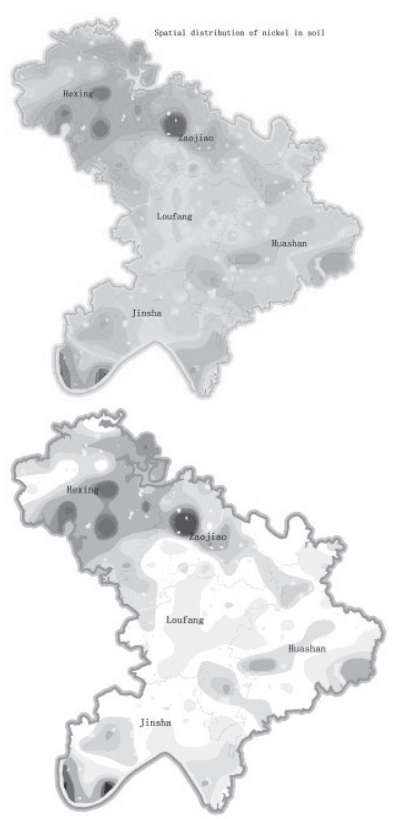

$\mathrm{Cr}$

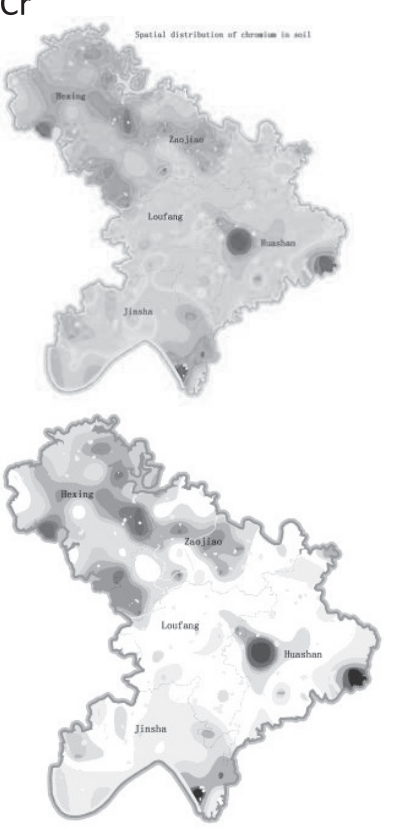

$\mathrm{Pb}$

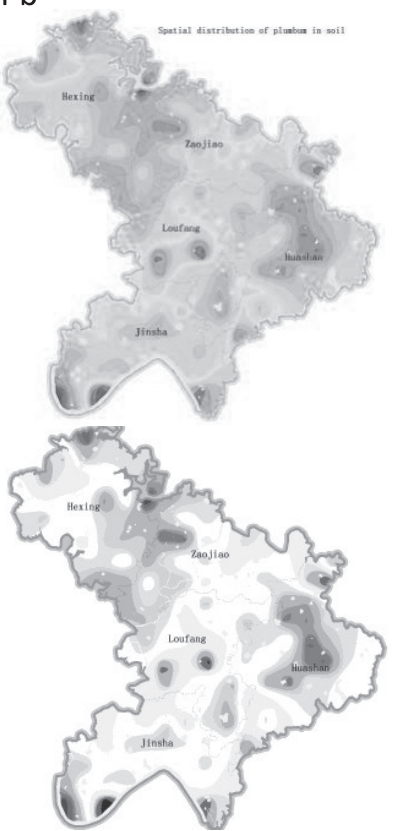

$\mathrm{Cu}$

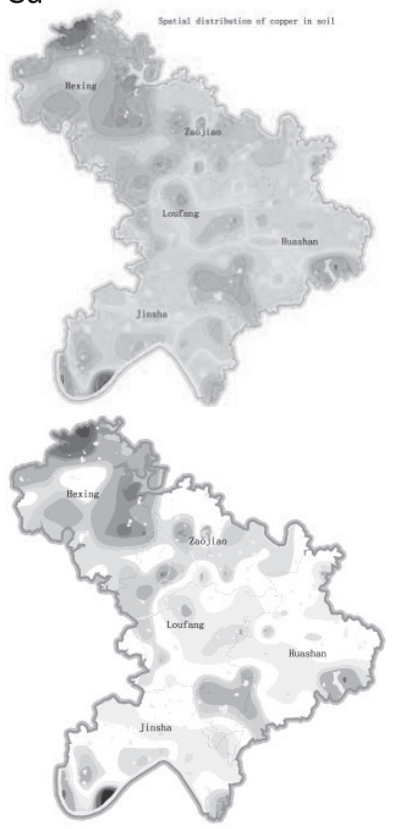

Zn

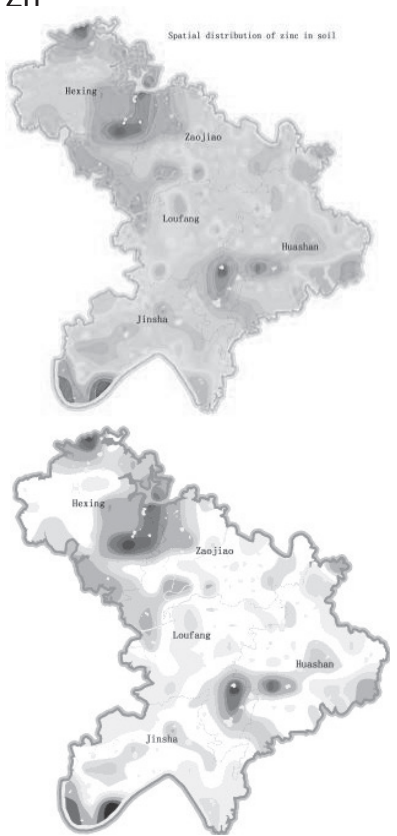

Fig. 2. Spatial distribution of different heavy metals on surface soil (dark representative element content is high, light representative element content is low). 
and biological degradation [31-34]. We found that parent materials and pedogenic processes were major factors contributing to high concentrations of heavy metals in
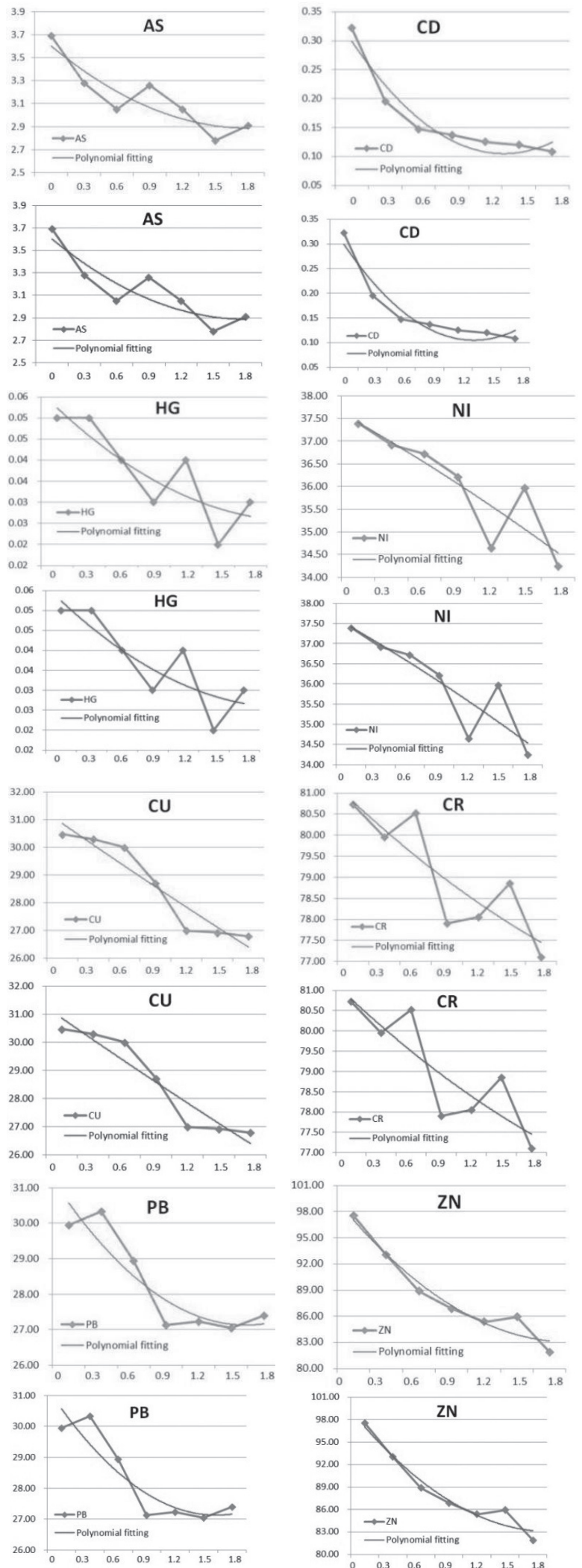

36.50
36.00

35.50

35.00
34.50

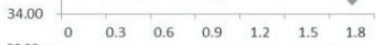

38.00

37.50
37.00

37.00
36.50
36.00

36.00

35.00
34.50
3400
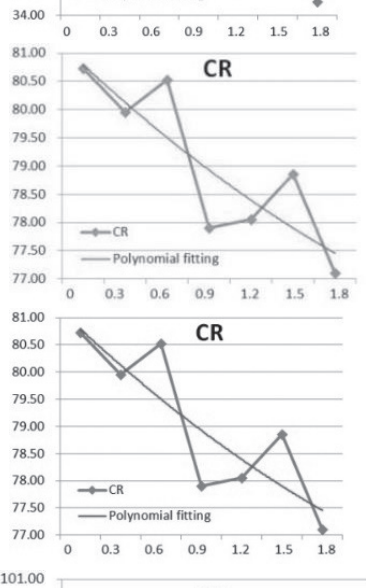

101.00

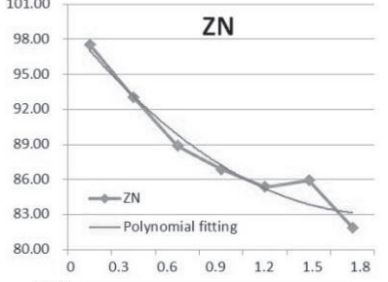

${ }_{101.00}^{0}$

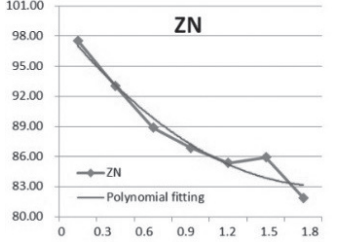

Fig. 3. Vertical change of heavy metal content in soil (Y unit for $\mathrm{ug} / \mathrm{g}, \mathrm{X}$ unit for meter). soil [26]. In the research area, soil mainly originated from quaternary eluvial, alluvial, and diluvial deposits. The exposed bedrock was a Jurassic Shaxi Miao formation (the lithology was purple, brown-red mudstone, and siltstone unstable feldspar quartz interbedded), and all the soil originated from the same parent material. There was no significant difference in space between soil and parent material. Heavy metals in the soil background values were consistent. According to the analysis of heavy metals content in rock (Table 2), the concentration of heavy metals in rock was lower than that of the surface soil.

Meanwhile, the vertical cross-section of heavy-metal soil showed a decreasing trend with increasing depth (Fig. 3 ), and with the increase in depth, the amount of variation decreased. This shows that heavy metal content tends to be stable at the depths of soil and it also indicates that heavy metals on the surface soil have super-imposed external sources.

Therefore, the original rock is not the reason for heavy metal accumulation in the surface soil.

Industrial activities cause heavy metal pollution in two ways. One is direct pollution, such as wastewater and solid waste [35-36]. The second is indirect pollution, such as atmospheric dust. Samples were collected from agricultural land where there was no direct wastewater or waste discharge. Therefore, industrial pollution was caused by atmospheric dust. In order to investigate if the heavy metals in the atmospheric dustfall had an impact on the topsoil, the content of heavy metals in the dustfall and the topsoil were compared. The results are shown in Table 2, including the average heavy metal content of all the samples.

Table 2 shows the heavy metal content in atmospheric dustfall. In addition to $\mathrm{Hg}$ and NI, the remaining elements' content was much higher than the background value of the topsoil. The $\mathrm{Zn}$ content in the atmospheric dustfall was 4.33 times greater than that of the topsoil, and the As, Cd, and $\mathrm{Pb}$ content in the atmospheric dustfall was 3.5 times higher than in the topsoil. This suggests that atmospheric particles settling into the soil was one of the external sources of heavy metals in the topsoil. By comparing the spatial distribution of heavy metals between the topsoil elements and the atmospheric dustfall, the spatial distribution of elements had a better consistency [37-38].

There was a road to the town in the west, north of Hexing village. The road was frequented by a large number of diesel vehicles and farm trucks in both directions. Heavy metals concentrations in the topsoil and the atmospheric dustfall had high values, which suggests that the atmospheric dust has an impact on the heavy metals in the soil. It is worth noting that the district had just built a concrete road to a school called the Hope School. Although currently there is no contamination, the near-surface portion of the heavy metal content in the atmospheric dustfall was relatively high, with the accumulation of atmospheric dustfall ultimately affecting soil quality. Similarly, in a place not far from Huashan village, a highway will be built which will have a great impact on the future of the soil and will require attention and monitoring. 
Table 2. Heavy metal content in atmospheric dustfall.

\begin{tabular}{|c|c|c|c|c|c|}
\hline \multirow[b]{2}{*}{ Topsoil and rock Index } & \multicolumn{5}{|c|}{ Heavy metal content $(\mu \mathrm{g} / \mathrm{g})$} \\
\hline & $\begin{array}{c}\text { Atmospheric dustfall } \\
\text { (AD) }\end{array}$ & $\begin{array}{c}\text { Topsoil } \\
\text { (TS) }\end{array}$ & $\begin{array}{c}\text { Rock } \\
\text { (R) }\end{array}$ & $\mathrm{AD} / \mathrm{TS}$ & $\mathrm{TS} / \mathrm{R}$ \\
\hline As & 13.16 & 3.54 & 2.02 & 3.72 & 1.75 \\
\hline $\mathrm{Cd}$ & 1.59 & 0.40 & 0.23 & 3.98 & 1.74 \\
\hline \multicolumn{2}{|c|}{$\begin{array}{c}\mathrm{Cr} \\
93.6\end{array}$} & 75.21 & 56.28 & 1.24 & 1.34 \\
\hline $\mathrm{Cu}$ & 54.73 & 28.01 & 17.37 & 1.95 & 1.61 \\
\hline $\mathrm{Hg}$ & 0.25 & 0.49 & 0.01 & 0.50 & 49 \\
\hline $\mathrm{NI}$ & 30.3 & 33.24 & 27.57 & 0.91 & 1.21 \\
\hline $\mathrm{Pb}$ & 104.72 & 29.88 & 23.54 & 3. 50 & 1.27 \\
\hline $\mathrm{Zn}$ & 413.52 & 95.392 & 60.78 & 4. 33 & 1.57 \\
\hline
\end{tabular}

In the present study, soil samples were collected from agricultural soil. A previous study [24] found that enrichment of $\mathrm{Cd}, \mathrm{Cu}$, and $\mathrm{Zn}$ in agricultural soil was closely correlated to agricultural production. For example, cadmium is usually considered a marker element for agronomic practices, which includes the use of chemical fertilizers such as phosphate fertilizers, livestock manure, etc. [28]. Annual $\mathrm{Cd}$ input to agricultural soil in China has been reported as 113,778 , and $30 \mathrm{t}$ for total fertilizers, livestock manures, and irrigation water, respectively [30]. Additionally, $\mathrm{Zn}$ and $\mathrm{Zn}$ compounds are widely used as agricultural fertilizers, and cattle slurry contains a significant amount of $\mathrm{Zn}$ and $\mathrm{Cu}$ since these elements are fed to cattle as a trace metal supplement $[29,39]$. In the research area, enrichment of heavy metals $(\mathrm{Cd}, \mathrm{Cu}$, and $\mathrm{Zn}$ ) had a good correlation with the production of rice, and in turn rice production has a direct relationship with fertilizer use. So, agricultural production is a main source of heavy metal pollution.

Irrigation water was collected in the research area and was the corresponding total of six sediment samples from reservoirs, ponds, and rivers [40-41]. Table 3 shows the

Table 3. Heavy metal content in water environment $\left(\mu \mathrm{g} / \mathrm{g}^{-1}\right)$.

\begin{tabular}{|c|c|c|c|c|c|c|c|c|}
\hline Index & $\mathrm{As}$ & $\mathrm{Cd}$ & $\mathrm{Cr}$ & $\mathrm{Cu}$ & $\mathrm{Hg}$ & $\mathrm{Ni}$ & $\mathrm{Pb}$ & $\mathrm{Zn}$ \\
\hline Water & 1.34 & 0.23 & $<0.01$ & 2.87 & 0.02 & $\mathbf{6 . 8 6}$ & $\mathbf{9 . 8 5}$ & $\mathbf{2 4 . 5 9}$ \\
\hline Sediment & 2.51 & 0.34 & 69.55 & 26.72 & 0.03 & 35.02 & 27.06 & 75.64 \\
\hline Topsoil & 3.54 & 0.40 & 75.21 & 28.01 & 0.49 & 33.24 & 29.88 & 95.39 \\
\hline
\end{tabular}

Table 4. Heavy metal content in plant and root soil $\left(\mu \mathrm{g} / \mathrm{g}^{-1}\right)$.

\begin{tabular}{|c|c|c|c|c|c|c|c|c|}
\hline Type & $\mathrm{As}$ & $\mathrm{Cd}$ & $\mathrm{Cr}$ & $\mathrm{Cu}$ & $\mathrm{Hg}$ & $\mathrm{Ni}$ & $\mathrm{Pb}$ & $\mathrm{Zn}$ \\
\hline Rice & 0.118 & 0.010 & 0.173 & 5.719 & 0.003 & 0.067 & 0.038 & 13.570 \\
Root soil & 2.939 & 0.711 & 72.091 & 27.454 & 0.056 & 0.858 & 28.236 & 95.100 \\
Root soil /rice & 24.9 & 71.1 & 416.7 & $\mathbf{4 . 8}$ & 18.7 & 12.8 & 743.0 & $\mathbf{7 . 0}$ \\
\hline Peanut & 0.016 & 0.091 & 0.122 & 12.910 & 0.002 & 0.041 & 0.095 & 45.413 \\
Root soil & 3.36 & 0.441 & 73.5 & 26.8 & 0.03 & 1.06 & 27.7 & 96.8 \\
Root soil /peanut & 210.0 & $\mathbf{4 . 8}$ & 602.4 & $\mathbf{2 . 0}$ & 15.0 & 25.8 & 291.5 & $\mathbf{2 . 1}$ \\
\hline Soybean & 0.030 & 0.080 & 0.121 & 16.420 & 0.001 & 0.070 & 0.034 & 53.201 \\
Root soil & 3.25 & 0.461 & 74.8 & 27.6 & 0.034 & 0.852 & 26.8 & 95.5 \\
Root soil /soybean & 108.3 & $\mathbf{5 . 8}$ & 618.2 & $\mathbf{1 . 7}$ & 34 & 12.2 & 788.2 & $\mathbf{1 . 8}$ \\
\hline Grapefruit & 0.028 & 0.001 & 0.110 & 3.370 & 0.001 & 0.015 & 0.015 & 1.370 \\
Root soil & 2.49 & 0.490 & 68.9 & 32.8 & 0.034 & 0.693 & 26.7 & 101 \\
Root soil / grapefruit & 88.9 & 490.0 & 626.4 & $\mathbf{9 . 7}$ & 34 & 46.2 & 1780 & 73.7 \\
\hline Sweet potato & 0.017 & 0.012 & 0.164 & 15.424 & 0.002 & 0.092 & 0.096 & 28.012 \\
Root soil & 5.33 & 0.880 & 74.6 & 32.3 & 0.035 & 1.10 & 37.5 & 116 \\
Root soil / sweet potato & 313.5 & 73.3 & 454.8 & $\mathbf{2 . 1}$ & 17.5 & 11.9 & 390.6 & $\mathbf{4 . 1}$ \\
\hline
\end{tabular}


average heavy metal content of all the samples. As can be seen, the heavy metal content in the water was below that of the topsoil. The heavy metal content in the sediment and soil background value was basically the same, indicating that the influence of soil heavy metals on water is limited.

The research area has collected crops (rice, peanuts, sweet potatoes, and grapefruit) and corresponding root soil for a total of 15 sets. Table 4 shows the various types of plants and their corresponding roots with heavy metal content in the soil. All the samples were from the fruit of plants. As the table shows, most of the heavy metal content of root soil was dozens of times or even 100 times that found in the plant. Only individual heavy metals content was not very different between plants and root soil and this only occurred a few times. High $\mathrm{Cd}$ content of the research area can be seen in Table 4 . The soybean has a strong ability to accumulate $\mathrm{Cd}$, therefore its planting should be reduced to reduce the distribution of $\mathrm{Cd}$. It can also be seen from Table 4 that $\mathrm{Cu}$ has a beneficial effect on various types of plants gathered, but $\mathrm{Cu}$ content in the research area did not reach hazardous levels, and therefore the impact of $\mathrm{Cu}$ could not be determined. The $\mathrm{Zn}$ content was higher in the research area and the $\mathrm{Zn}$ found on rice, soybeans, and other crops had a good enriching effect on the crop while it had little effect on the grapefruit. Therefore, the type of vegetation should be adjusted according to $\mathrm{Zn}$ distribution.

\section{Conclusions}

This paper collected a large number of samples, including 173 topsoil, 11 atmospheric dustfall, six water and sediment, and 15 core samples. Eight heavy metals were identified and their content was determined for all of the samples. This paper presents the concept of using the ordinary Kriging method to generate the spatial distribution of heavy metals in the research area. By analyzing the spatial distribution of heavy metals in the soil, it was found that the distribution of heavy metals is various. By analyzing the content of heavy metals in original rock, atmospheric dustfall, and agricultural production, it can be found that the differences of heavy metals in soil are derived from atmospheric dustfall and agricultural production, which differs depending on the specific environments. This suggests that attention should be paid to environmental protection while developing the economy. In this paper, the effects of heavy metals on the water environment and crops were also analyzed. Analysis showed that the influence of various elements was different. For the water environment, the influence of $\mathrm{Zn}, \mathrm{Pb}$, and $\mathrm{Ni}$ was significant. For the core samples, the influence of $\mathrm{Zn}$ and $\mathrm{Cu}$ was significant. This study can indicate the choice of crops in order to ensure the low adsorption rate of heavy metals.

\section{Acknowledgments}

This work was supported by the Natural Science Foundation of China (No.41102225), the Scientific Innovation Team of Remote Sensing Science and Technology of Chengdu University of Technology(Grant No.KYTD201501).

\section{References}

1. MORGAN R.P.C. Soil Erosion and Conservation. J. John Wiley \& Sons. 2009.

2. LIU Z.C., GAO L.M., LIU L., ZHANG X.X. A Comparative Analysis of Environmental Quality Assessment Methods - a Case Study of Heavy Metal-Contaminated Soil. Proceedings of 2015 International Conference on Materials, Environmental and Biological Engineering. 2015.

3. WANG Q.Y., LIU J.S., CHENG S. Heavy metals in apple orchard soils and fruits and their health risks in Liaodong Peninsula, Northeast China. J. Environ. Monit. Assess. 187, 4178, 2015.

4. ZHOU L.L., YANG B., XUE N.D., LI F.S., SEIP H.M., CONG X., YAN Y.Z., LIU B., HAN B.L., LI H.Y. Ecological risks and potential sources of heavy metals in agricultural soils from Huanghuai Plain, China. J. Environ SciPollut R. 21, 1360, 2014.

5. KHURANA M.P., JHANJI S. Infuence of cadmium on dry matter yield, micronutrient content and its uptake in some crops. J. Journal of Environmental biology. 35 (5), 865, 2014.

6. HE X.H., FAN F.X., YUAN X.W., ZHU W.X., LIU N., PING Q., LIU J.S. Distribution, Chemical Speciation, and Environmental Risk Assessment of Heavy Metals in Tailings Soils near Dexing Copper Mine, China. J. Journal of Donghua University (English Edition). 5 (29), 405, 2012.

7. LI J.H, LU Y., YIN W., GAN H.H., ZHANG C., DENG X.L., LIAN J. Distribution of heavy metals in agricultural soils near a petrochemical complex in Guangzhou, China. J. Environ Monit Assess. 153, 365, 2009.

8. THAPLIYAL A., VASUDEVAN P., DASTIDAR M.G., TANDON M. Irrigation with domestic wastewater:responses on growth and yield of ladyfinger Abelmoschus esculentus and on soil nutrients. J. Journal of Environmental Biology. 32 (5), 645, 2011.

9. LU D.W., LI Z.X., CHEN J.T., LIU Y., ZHANG Z.Q., LIANG J.P., LIU H.Y. Potential Changes in Net Primary Productivity and Carbon Input of Periurban Agroecosystems Treated with Biosolids in Buenos Aires, Argentina. J. Journal of Earth Science. 2 (26), 273, 2015.

10. AOUDEK P., NEJEDLY J., LUKA P., PETROVA A., VANEK T. The Sorghum Plants Utilization For Accumulation of Heavy Metals. Proceedings of $20133^{\text {rd }}$ International Conference on Energy and Environmental Science. 2013.

11. PAN K., WANG W.X. Trace metal contamination in estuarine and coastal environments in China. Sci. J. Total Environ. 421, 3-16 (2013), 2012.

12. LIU Y., WANG H.F., LI X.T, LI J.C. Heavy Metal Contamination of Agricultural Soils in Taiyuan, China. J. Pedosphere. 25 (6), 901, 2015. 
13. SHAO X.X., HUANG B., ZHAO Y.C., SUN W.X., GU Z.Q., QIAN W.F. Impacts of human activities and sampling strategies on soil heavy metal distribution in a rapidly developing region of China. Ecotoxicol. J. Environ. Saf. 104, $1,2014$.

14. SONG W., CHEN B.M., LIU L. Soil heavy metal pollution of cultivated land in China. J. Res. Soil Water Conserv. 20 (2), 293, 2013

15. LIU Z.C, GAO L.M., LIU N., ZHANG X.X. A Comparative Analysis of Environmental Quality Assessment Methods - a Case Study of Heavy Metal-Contaminated Soil. Proceedings of 2015 International Conference on Materials,Environmental and Biological Engineering. 2015.

16. PAN L.B., WANG S.Y., MA, J., FANG D. Gridded field observations of polycyclic aromatic hydrocarbons in soils from a typical county in Shanxi Province, China. J. Arch. Environ. Contam. Toxicol. 68, 323, 2015.

17. BI C.J., CHEN Z.L., WANG J., ZHOU D. Quantitative Assessment of Soil Health Under Different Planting Patterns and Soil Types. J. Pedosphere . 23 (2), 194, 2013.

18. MARCHETTI A., PICCINI C., FRANCAVIGLIA R., MABIT L. Spatial Distribution of Soil Organic Matter Using Geostatistics: A Key Indicator to Assess Soil Degradation Status in Central Italy. J. Pedosphere. 22 (2), 230, 2012.

19. STEIN M.L. On a class of space-time intrinsic random functions. J. Bernoulli. 2 (19), 387, 2013.

20. LIU H., SHI J.C. Reconstruction and analysis of temporal and spatial variations in surface soil moisture in China using remote sensing. J. Chinese Science Bulletin. 22 (57), 2824, 2012.

21. WANG G., LIU L.P., DING Y.Y. Improvement of Radar Quantitative Precipitation Estimation Based on Real-Time Adjustments to Z-R Relationships and Inverse Distance Weighting Correction Schemes. J. Advances in Atmospheric Sciences. 3 (29), 575, 1996, 2012.

22. CAO X.Q., WAN J.W., CHEN W., WANG C. Soil Element Background Values - a Case Study of Region in Southern China. J. Safety and Environmental Engineering. 2 (16), 27, 2009.

23. WANG Y.C., QIAO M., LIU Y.X., ZHU Y.G. Health risk assessment of heavy metals in soils and vegetables from wastewater irrigated area, Beijing-Tianjin city cluster,China. J. Journal of Environmental Sciences. 24 (4), 690, 2012.

24. LI Y.H., Liu H.B. Spatial distribution of heavy metals in agricultural soil in Wutan, China. Environmental Science and Information Application Technology. 2009.

25. LU A.X., WANG J.H., QIN X.Y., WANG K.Y., HAN P., ZHANG S.Z. Multivariate and geostatistical analyses of the spatial distribution and origin of heavy metals in the agricultural soils in Shunyi, Beijing, China. Sci. J. Total Environ. 425, 66-74, 2012.

26. XU X.H., ZHAO Y.C., ZHAO X.Y., WANG Y.D., DENG W.J. Sources of heavy metal pollution in agricultural soils of a rapidly industrializing area in the Yangtze Delta of China. J. Ecotox. Environ. Safe. 108, 171, 2014.

27. ZHANG L.Y., LIU Y., QIAO B.Q., FU C., WANG H.B., HUANG Y.M., YANG F.M. Characteristics of Atmospheric
Dry and Wet Deposition of Trace Metals in Hinterland of Three Gorges Reservoir. J. Environmental Science. 2 (37), 466, 2016.

28. SUN C.Y., LIU J.H., WANG Y., SUN L.Q., YU H.W. Multivariate and Geostatistical Analyses of the Spatial Distribution and Sources of Heavy Metals in Agricultural Soil in Dehui, Northeast China. J. Chemosphere. 92, 517523, 2013.

29. LIU Y.S., HU Z.C., ZONG K.Q., GAO C. GU., GAO S., XU J., CHEN H.H. Reappraisement and refinement of zircon $\mathrm{U}-\mathrm{Pb}$ isotope and trace element analyses by LA-ICP-MS. J. Chinese Science Bulletin. 15 (55), 1535. 2010.

30. LUO L., MA Y., ZHANG S., WEI D., ZHU Y.G. An inventory of trace element inputs to agricultural soils in China. J. Environ. Manage. 90, 2524, 2009.

31. STANISZEWSKI R. Heavy Metals in Waters and Sediments of Rivers Affected by Brown Coal Mine Waters. J. Polish Journal of Environmental Studies. 6 (23), 2217, 2014.

32. AKKALA A., DEVABHAKTUNI V., KUMAR A. Interpolation techniques and associated software for environmental data. J. Environmental Progress \& Sustainable Energy. 29, 134, 2010.

33. PATEL K.S., SHARMA R., DAHARIYA N.S., R.K., BLAZHEV B., MATINI L. Black Carbon and Heavy Metal Contamination of Soil. J. Polish Journal of Environmental Studies. 2 (25), 859, 2016.

34. WANG Y.C., LIANG A., BO L., SHENG Z. Assessment of Heavy Metal Contamination from Sediment and Soil in the Riparian Zone China's Three Gorges Reservoir. J. Polish Journal of Environmental Studies. 5 (24), 2253, 2015.

35. ZHENG G.G., ZHOU D.S., WEI X.P., ZHANG Q. Reconfiguration of face expressions based on the discrete capture data of radial basis function interpolation. J. Advances in Atmospheric Sciences. 2 (22), 26, 2010.

36. HUANG G., LIU Y., HUANG R.H. The Interannual Variability of Summer Rainfall in the Arid and Semiarid Regions of Northern China and Its Association with the Northern Hemisphere Circumglobal Teleconnection. J. Advances in Atmospheric Sciences. 2 (28), 257, 2011.

37. CHEN Z.X., CAO F.L. Spherical Scattered Data Quasiinterpolation by Gaussian Radial Basis Function. Communications in Mathematical Research. J. 36B (3), 401, 2015.

38. ZHU H.Q., LIU X.K., WANG H.Y., LIU Y. Optimal Choice of Staff for Coal Mine Safety Evaluation and Management Based on Gray Statistical Method. Proceedings of $20112^{\text {nd }}$ IEEE International Conference on Emergency Management and Management Sciences. 2011.

39. XU J.L., WEN X.P., YU M., LI C., WANG J., ZHANG L.J., ZHOU Y., QIAO X. Remote Sensing Linear Structural Analysis Huize $\mathrm{Pb}$ - $\mathrm{Zn}$ Based on the Principle of Geostatistics. J. Geology and Exploration. 4 (50), 763, 2014.

40. DAI H.Y., REN L.Y., WANG M., XUE H.B. Water distribution extracted from mining subsidence area using Kriging interpolation algorithm J. Transactions of Nonferrous Metals Society of China. 21, 723, 2011.

41. POKHREL R.M., KUWANO J., TACHIBANA H. A kriging method of interpolation used to map liquefaction potential over alluvial ground. J. Eng. Geol. 152 (1), 26. 